\title{
The Journal of \\ Thoracic and Cardiovascular Surgery
}

Vol 132, No. 4, October 2006

\section{Table of Contents}

Presidential Address

Editorial
747 Presidential Address 2003

Joel Cooper, MD, Philadelphia, Pa
753 Our destination and our destiny: Real endoscopic cardiac surgery

W. Randolph Chitwood, Jr, MD, Greenville, $N C$

\section{General Thoracic Surgery (GTS)}

Surgical treatment of tumors of the proximal stomach with involvement of the distal esophagus: A 26-year experience with Siewert type III tumors $\sqrt{\mathcal{B}}$ K. Robert Shen, MD, Stephen D. Cassivi, MD, MSc, Claude Deschamps, MD, Mark S. Allen, MD, Francis C. Nichols III, MD, W. Scott Harmsen, MS, and Peter C. Pairolero, MD, Rochester, Minn

A 26-year series of gastrectomy with distal esophagectomy for patients with proximal stomach cancers involving the distal esophagus (Siewert type III tumors) reports long-term survival with significant prognostic factors. Although often palliative, long-term survival is possible in patients with completely resected, early-stage, low-grade cancers.

763 Positron emission tomography predicts survival in malignant pleural mesothelioma

Raja M. Flores, MD, Timothy Akhurst, MD, Mithat Gonen, PhD,

Maureen Zakowski, MD, Joseph Dycoco, BA, Steven M. Larson, MD, and

Valerie W. Rusch, MD, New York, New York

Maximum FDG-PET SUV predicts survival in malignant pleural mesothelioma

769 Radical sublobar resection for small-sized non-small cell lung cancer: A multicenter study

Morihito Okada, MD, PhD, Teruaki Koike, MD, PhD, Masahiko Higashiyama, MD, PhD, Yasushi Yamato, MD, PhD, Ken Kodama, MD, PhD, and Noriaki Tsubota, MD, PhD, Akashi City, Hyogo, Niigata City, Niigata, and Osaka City, Osaka, Japan

The study demonstrated that recurrence and survival associated with sublobar resection $(n=305)$ were not inferior to those obtained with lobectomy $(n=262)$ in patients with stage IA non-small cell lung cancer $2 \mathrm{~cm}$ or smaller who were able to tolerate a lobectomy. Postoperative lung function was significantly better in patients who underwent sublobar resection. 


\section{Surgery for Acquired Cardiovascular Disease (ACD)}

776 Endoscopic robotic mitral valve surgery $\boldsymbol{\Delta}$

Douglas A. Murphy, MD, Jeffrey S. Miller, MD, David A. Langford, MD, and Averel B. Snyder, MD, Atlanta, Ga

We describe our 3-year experience using robotic instrumentation to approach the mitral valve endoscopically from the right lateral chest. This technique was associated with low morbidity and mortality, and a high rate of mitral repair was achieved with satisfactory short-term results.

782 Treatment of postoperative sternal dehiscence with mediastinitis:

Twenty-four-year use of a single method

J. Ernesto Molina, MD, PhD, Elaine C. Nelson, RN, CNS, and Robin R. A. Smith, RN, CNP, Minneapolis, Minn

A technique for repair of postoperative sternal dehiscence with mediastinitis is reported with a $98 \%$ success rate, leaving the sternum intact without the use of muscle flaps.

788 Temporal disparity in the induction of matrix metalloproteinases and tissue inhibitors of metalloproteinases after thoracic aortic aneurysm formation John R. Barbour, MD, Robert E. Stroud, MS, Abigail S. Lowry, BS, Leslie L. Clark, MS, Allyson M. Leone, BS, Jeffery A. Jones, PhD, Francis G. Spinale, MD, PhD, and John S. Ikonomidis, MD, PhD, Charleston, SC

The specific temporal matrix metalloproteinase (MMP)/tissue inhibitor of metalloproteinases (TIMP) abundance pattern with the induction and progression of experimental thoracic aortic aneurysms (TAAs) was evaluated. Unique early and late MMP/TIMP relationships exist during TAA formation, which might represent phases of the natural history of TAA progression and thereby hold different temporal windows of diagnostic and therapeutic relevance.

796 Apicoaortic valved conduit: Potential for progress?

Ulf Lockowandt, MD, PhD, Stockholm, Sweden

Techniques and outcomes of thirteen cases of apicoaortic valved conduit insertions in high-risk patients are described. Nine procedures were performed off pump.

802 The effect of diabetes mellitus on patients undergoing coronary surgery: A risk-adjusted analysis

Chanaka Rajakaruna, MRCS, Chris A. Rogers, PhD, Chinthaki Suranimala, MRCS, Gianni D. Angelini, MD, FRCS, and Raimondo Ascione, MD, FRCS, Bristol, United Kingdom

We investigated the effect of diabetes mellitus on short- and long-term outcome of CABG surgery. Our results indicate that early mortality and morbidity is low. The negative effect of diabetes mellitus on long-term survival and cardiac-related events remains a problem.

811 Different patterns of aortic wall elasticity in patients with Marfan syndrome: A noninvasive follow-up study

Daniela Baumgartner, MD, Christian Baumgartner, PhD, Elisabeth Schermer, MD, Georg Engl, MD, Ulrich Schweigmann, MD, Gabor Mátyás, PhD, Beat Steinmann, MD, and Jörg Ingolf Stein, MD, Innsbruck and Tyrol, Austria, and Zurich and Schwerzenbach, Switzerland

Noninvasively determined aortic elastic properties distinguished between 46 patients with Marfan syndrome and 46 healthy controls with high sensitivity and specificity. Cluster analysis revealed 4 patterns of aortic wall alterations. During $39 \pm 16$ months of $\beta$-blocker treatment, aortic elasticity improved in $70 \%$ and deteriorated in $30 \%$ of patients. 


\section{Surgery for Congenital Heart Disease (CHD)}

820 Proteomics of cerebral injury in a neonatal model of cardiopulmonary bypass with deep hypothermic circulatory arrest $\mathcal{\beta}$ Amir M. Sheikh, MBBS, MRCS, Cindy Barrett, MD, Nestor Villamizar, MD, Oscar Alzate, PhD, Sara Miller, PhD, John Shelburne, MD, PhD, Andrew Lodge, MD, Jeffrey Lawson, $M D, P h D$, and James Jaggers, $M D$, Durham, NC

Neurologic morbidity remains a concern after DHCA. Using proteomics, we characterized acute protein changes in brain neocortex of piglets subjected to CPB with 1 hour of DHCA. Findings were correlated to histologic and ultrastructural evidence of cerebral injury. ApoA1 expression was found to decrease.

829 Can pulmonary conduit dysfunction and failure be reduced in infants and children less than age 2 years at initial implantation? $\beta$

Tara Karamlou, MD, Eugene H. Blackstone, MD, John A. Hawkins, MD,

Marshall L. Jacobs, MD, Kirk R. Kanter, MD, John W. Brown, MD,

Constantine Mavroudis, MD, Christopher A. Caldarone, MD, William G. Williams, MD, Brian W. McCrindle, MD, MPH, and the Pulmonary Conduit Working Group for the members of the Congenital Heart Surgeons Society, Toronto, Ontario, Canada, Cleveland, Ohio, Salt Lake City, Utah, Philadelphia, Pa, Atlanta, Ga, Indianapolis, Ind, and Chicago, Ill

Conduit-related intervention was common in children undergoing initial ventricle-pulmonary artery valved conduit insertion at less than 2 years of age. Conduit durability and hemodynamic function can be improved by using conduits with a Z-score between +1 and +3 .

839 Brain oxygen and metabolism during circulatory arrest with intermittent brief periods of low-flow cardiopulmonary bypass in newborn piglets Steven Schultz, MD, Diego Antoni, MD, Gregory Shears, MD, Scott Markowitz, MD, Peter Pastuszko, MD, William Greeley, MD, David F. Wilson, PhD, and Anna Pastuszko, PhD, Miami, Fla, Philadelphia, Pa, Rochester, Minn, and Oklahoma City, Okla

Interrupting DHCA with periods of low flow can prolong the "safe" period of DHCA. This safe time is dependent on the rate flow of intermittent low-flow CPB. A flow of $80 \mathrm{~mL} \cdot \mathrm{kg}^{-1}$. $\min ^{-1}$ is sufficient to increase the cortical oxygen to greater than $20 \mathrm{~mm} \mathrm{Hg}$ and delay the increase in extracellular dopamine by 15 minutes as compared with DHCA alone.

845 Intermediate-term outcomes of the arterial switch operation for transposition of great arteries in neonates: Alive but well? $\beta$

Darren H. Freed, MD, PhD, Charlene M. T. Robertson, MD, Reginald S. Sauve, MD, Ari R. Joffe, MD, Ivan M. Rebeyka, MD, David B. Ross, MD, and John D. Dyck, MD, the Western Canadian Complex Pediatric Therapies Project Follow-up Group, Edmonton and Calgary, Alberta, Winnipeg, Manitoba, and Saskatoon and Regina, Saskatchewan, Canada

This 18- to 24-month arterial switch operation follow-up for 88 neonates shows low mortality $(1.1 \%)$; low reintervention at 4-year average (6.8\%); delayed motor scores $(6.1 \%)$, an improvement over previous studies; and delayed mental scores (17.1\%), a cause for concern. Preoperative variables correctly classified $84.1 \%$ of delayed children, suggesting potential for improvement. 


\section{Evolving Technology \\ (ET)}

853 Efficacy and safety of right and left atrial ablations on the beating heart with irrigated bipolar radiofrequency energy: A long-term animal study Spencer J. Melby, MD, Sydney L. Gaynor, MD, Jordon G. Lubahn, BS, Anson M. Lee, MD, Paymon Rahgozar, BS, Shelton D. Caruthers, PhD, Todd A. Williams, RT, Richard B. Schuessler, PhD, and Ralph J. Damiano, Jr, MD, St Louis, Mo

The Cox maze procedure is highly effective in the treatment of atrial fibrillation. Modifications to the traditional procedure were made with an irrigated bipolar radiofrequency ablation device. Lesions were $99 \%$ transmural, and the procedure was successfully performed on the beating hearts of 6 pigs without CPB.

861 Drug-eluting stents versus arterial myocardial revascularization in patients with diabetes mellitus

Yanai Ben-Gal, MD, Rephael Mohr, MD, Gideon Uretzky, MD, Benjamin Medalion, MD, Alberto Hendler, MD, Natalie Hansson, BmedSc, Itzhak Herz, MD, and Yaron Moshkovitz, MD, Tel Aviv and Petach Tikva, Israel

Arterial coronary artery bypass grafting was compared, after propensity score matching, with percutaneous coronary intervention incorporating drug-eluting stents in diabetic patients. After 19 months' follow-up, angina return and reinterventions were significantly more frequent in the stent group.

867 Mesothelium regeneration on acellular bovine pericardia loaded with an angiogenic agent (ginsenoside $\mathbf{R g}_{1}$ ) successfully reduces postsurgical pericardial adhesions $\widehat{\vartheta}$

Yen Chang, MD, Po-Hong Lai, MS, Chung-Chi Wang, MD, Sung-Ching Chen, PhD,

Wei-Chun Chang, MS, and Hsing-Wen Sung, PhD, Taipei and Hsinchu, Taiwan

A porous acellular bovine pericardium loaded with ginsenoside $\operatorname{Rg}_{1}$ (the Acellular $/ \operatorname{Rg}_{1}$ patch) was used as a substitute to repair a pericardial defect created in a rabbit model. Mesothelium regeneration was observed on each side of the Acellular/ $\mathrm{Rg}_{1}$ patch and successfully reduced the formation of pericardial adhesions.

\section{Cardiopulmonary Support and Physiology (CSP)}

875 Myocardial protection in the failing heart: I. Effect of cardioplegia and the beating state under simulated left ventricular restoration Monica Kostelec, MD, James Covell, MD, Gerald D. Buckberg, MD, Ahmad Sadeghi, MD, Julien I. E. Hoffman, MD, and Ghassan S. Kassab, PhD, San Diego, Los Angeles, San Francisco, and Irvine, Calif

Heart failure was induced by cardiac pacing to evaluate myocardial flow in LV restoration during cardioplegia and in beating state. The beating-heart method provided more endocardial flow during ventricular exposure. Vascular remodeling raised coronary vascular resistance in failing hearts, requiring higher pressure for similar blood flows. 
884 Myocardial protection in the failing heart: II. Effect of pulsatile cardioplegic perfusion under simulated left ventricular restoration

Ghassan S. Kassab, PhD, Monica Kostelec, MD, Gerald D. Buckberg, MD, James Covell, MD, Ahmad Sadeghi, MD, and Julien I. E. Hoffman, MD, Irvine, San Diego, Los Angeles, Pasadena, and San Francisco, Calif

Subendocardial coronary perfusion comparisons during simulated restoration of normal and failing hearts showed beating flow is unaltered, falls $154 \%$ with nonpulsatile cardioplegia, but exceeds beating flow (41\%) after pulsatile cardioplegia delivery. Beating or pulsatile cardioplegia better maintains subendocardial flow than nonpulsatile cardioplegia in open failing ventricles.

891 A combination of omental flap and growth factor therapy induces arteriogenesis and increases myocardial perfusion in chronic myocardial ischemia: Evolving concept of biologic coronary artery bypass grafting $\beta$ Kiyoaki Takaba, MD, Chunli Jiang, MD, Shintaro Nemoto, MD, PhD, Yoshiaki Saji, MD, Tadashi Ikeda, MD, PhD, Shinichi Urayama, MS, Takashi Azuma, BS, Akishige Hokugo, DDS, PhD, Sadami Tsutsumi, PhD, Yasuhiko Tabata, PhD, DMedSc, DPharm, and Masashi Komeda, MD, PhD, Kyoto, Japan

We combined a method using an omental flap and bFGF-induced arteriogenesis and provided adequate perfusion via the GEA as an extracardiac blood source to ameliorate regional cardiac dysfunction in a rabbit model of chronic myocardial ischemia.

900 Strain-related regional alterations of calcium-handling proteins in myocardial remodeling

Ahmet Kilic, MD, Tieluo Li, MD, Timothy D. C. Nolan, MS, Jennifer R. Nash, MS,

Shuying Li, MD, Deyanira J. Prastein, MD, Gary Schwartzbauer, PhD, Sina L. Moainie, MD,

G. Kwame Yankey, MD, Christopher DeFilippi, MD, Zhongjun $W u, P h D$, and

Bartley P. Griffith, MD, Baltimore, Md

Regional differences in strain drive alterations of local protein expression in the remodeling myocardium via mechanotransduction.

909 Aprotinin use in thoracic aortic surgery: Safety and outcomes Artyom Sedrakyan, MD, PhD, Albert Wu, MD, MPH, George Sedrakyan, MD, Marie Diener-West, PhD, Maryann Tranquilli, RN, and John Elefteriades, MD, New Haven, Conn, Baltimore, Md, and Yerevan, Armenia

Patients treated with aprotinin and undergoing thoracic aortic surgery were case-matched to those not receiving aprotinin. Aprotinin use was associated with reductions in platelet transfusion, ventilation time, pulmonary complications, and permanent arrhythmias. These data indicate that aprotinin may be safe to use in thoracic aortic surgery. 
918 Grafted skeletal myoblast sheets attenuate myocardial remodeling in pacing-induced canine heart failure model

Hiroki Hata, MD, Goro Matsumiya, MD, PhD, Shigeru Miyagawa, MD, PhD,

Haruhiko Kondoh, MD, PhD, Naomasa Kawaguchi, MD, PhD, Nariaki Matsuura, MD, PhD,

Tatsuya Shimizu, MD, PhD, Teruo Okano, PhD, Hikaru Matsuda, MD, PhD, and

Yoshiki Sawa, MD, PhD, Osaka and Tokyo, Japan

We tested a novel cell delivery system using autologous skeletal myoblast grafts grown as sheets to treat a canine dilated cardiomyopathy model. Implantation of the grafts attenuated cardiac remodeling and improved cardiac performance. This method was feasible and effective, suggesting an innovative and promising strategy for treating end-stage dilated cardiomyopathy.

925 Pharmacologic relaxation of vein grafts is beneficial compared with pressure distention caused by upregulation of endothelial nitric oxide synthase and nitric oxide production

Ada W. Y. Chung, PhD, Pooja Rauniyar, BSc, Honglin Luo, MD, PhD, York N. Hsiang, MD, Cornelis van Breemen, DVM, PhD, and Elena B. Okon, PhD, Vancouver, British Columbia, Canada

In a porcine vein graft model we demonstrated that replacement of pressure distention with pharmacologic vasorelaxation upregulated endothelial nitric oxide synthase and nitric oxide production in vein grafts. This alternative technique might be beneficial in attenuating vascular remodeling and improving vein graft patency.

933 Retrograde cerebral perfusion with intermittent pressure augmentation provides adequate neuroprotection: Diffusion- and perfusion-weighted magnetic resonance imaging study in an experimental canine model Mitsuhiro Kawata, MD, Masaki Sekino, PhD, Shinichi Takamoto, MD, PhD, Shoogo Ueno, PhD, Sachiko Yamaguchi, MS, Kazuo Kitahori, MD, PhD, Hiroyuki Tsukihara, MD, Yoshihiro Suematsu, MD, PhD, Minoru Ono, MD, PhD, Noboru Motomura, MD, PhD, Tetsuro Morota, MD, PhD, and Arata Murakami, MD, PhD, Tokyo, Japan

A diffusion- and perfusion-weighted MRI study showed that retrograde cerebral perfusion with intermittent pressure augmentation provides adequate neuroprotection during deep hypothermic circulatory arrest by allowing high apparent diffusion coefficient values to be maintained.

941 Nonviral gene transfer of hepatocyte growth factor attenuates neurologic injury after spinal cord ischemia in rabbits

Enyi Shi, MD, PhD, Xiaojing Jiang, MD, Teruhisa Kazui, MD, PhD,

Naoki Washiyama, MD, PhD, Katsushi Yamashita, MD, PhD, Hitoshi Terada, MD, PhD, and Abul Hasan Muhammad Bashar, MBBS, PhD, Hamamatsu, Japan, and Shenyang, China

Rabbit spinal cord was induced by means of infrarenal aortic occlusion. The human hepatocyte growth factor (HGF) gene was transferred into the spinal cord by means of intrathecal injection of hemagglutinating virus of Japan envelope vector containing HGF expression plasmid. Prophylactic transfection of the HGF gene induced angiogenesis, decreased spinal cord edema, and attenuated the neurologic deficits caused by spinal cord ischemia. 
948 Aprotinin improves cerebral protection: Evidence from a survival porcine model

Vesa Anttila, MD, Ikuo Hagino, MD, Yusuke Iwata, MD, Bret A. Mettler, MD,

Hart G. W. Lidov, MD, David Zurakowski, PhD, and Richard A. Jonas, MD, Boston, Mass,

Oulu, Finland, and Washington, DC

Sixteen piglets received aprotinin or placebo before a 120-minute period of deep hypothermic circulatory arrest (DHCA) or low-flow cardiopulmonary bypass (CPB). During rewarming, the mean number of rolling and adherent leukocytes was significantly lower after aprotinin administration $(P<.05)$. Aprotinin mitigates the inflammatory response and improves neurologic outcome after a prolonged period of DHCA and low-flow CPB.

\section{Cardiothoracic} Transplantation (TX)
954 Extended use of extracorporeal membrane oxygenation after lung transplantation David P. Mason, MD, Daniel J. Boffa, MD, Sudish C. Murthy, MD, PhD,

Thomas R. Gildea, MD, Marie M. Budev, DO, Atul C. Mehta, MD, Ann M. McNeill, RN, Nicholas G. Smedira, MD, Jingyuan Feng, MS, Thomas W. Rice, MD,

Eugene H. Blackstone, MD, and B. Gösta Pettersson, MD, PhD, Cleveland, Ohio

Severe graft failure after lung transplantation is rare but carries a high mortality. ECMO provides lifesaving support for a substantial proportion of these patients, but complications are common. Best results are achieved in the setting of early graft failure or severe acute rejection, but not pneumonia or sepsis.

\section{Brief Communications}

e23 Left ventricular encasement after pneumonectomy: Case report

Sietske A. Smulders, MD, Johan T. Marcus, PhD, C. Tji-Joong Gan, MD,

Thomas G. Sutedja, MD, PhD, Frank W. J. M. Smeenk, MD, PhD, and

Anton Vonk-Noordegraaf, MD, PhD, Amsterdam, The Netherlands

descending aortic replacement

Masashi Kawamura, MD, Hitoshi Ogino, MD, Hitoshi Matsuda, MD, Kenji Minatoya, MD,

Hiroaki Sasaki, MD, and Soichiro Kitamura, MD, Osaka, Japan

963 Complex reconstruction of the thoracic aorta using a novel stent graft/graft prosthesis

Martin Misfeld, MD, PhD, Lennart Duebener, MD, and Hans-Hinrich Sievers, MD, Luebeck, Germany

965 A rare case of acute necrotizing eosinophilic myocarditis: Bridge to recovery with ventricular assist device support

Jaromir Kohout, MD, Francis D. Ferdinand, MD, Shotaro Imaizumi, MD,

Elena C. Holmes, NP, and Louis E. Samuels, MD, Wynnewood, $\mathrm{Pa}$

967 Left internal thoracic artery patch aortoplasty for repair of coarctation of the aorta

Vitaly Demyanchuk, MD, PhD, Larysa Naumova, MD, PhD, Mykhaylo Atamanyuk, MD, PhD, and Sergiy Dykukha, MD, PhD, Kyiv, Ukraine 
969 Challenges in early cardiothoracic surgery: Aortic homograft transplantation in coarctation, a 44-year follow-up R. von Wattenwyl, MD, M. T. R. Grapow, MD, D. C. Reineke, MD, and H.-R. Zerkowski, MD, Basel, Switzerland

970 Repair of anomalous right and circumflex coronary arteries arising from the pulmonary artery

Giovanni Battista Luciani, MD, Fauzia Vendrametto, MD, Luca Barozzi, MD,

Rainer Oberhollenzer, MD, Walter Pitscheider, MD, and Alessandro Mazzucco, MD, Verona and Bolzano, Italy

972 Bronchogenic cyst: Unexpected finding in a large aneurysm of the pars membranacea septi

Frediano Inzani, MD, Franco Recusani, MD, Manuela Agozzino, MD,

Alessandra Cavallero, MD, Paolo M. De Siena, MD, Andrea D’Armini, MD, Mario Viganò, and Eloisa Arbustini, MD, Pavia, Italy

974 Coronary artery bypass grafting and biventricular pacing efficacy: Do past trials dictate a change in future practice?

Omid Hajiseyedjavadi, MD, MSc, Michael Pasque, MD, Marc Moon, MD,

Ralph Damiano, MD, Teodoro Mucha, BS, Keith Hebert, BS, and Nader Moazami, MD,

St Louis, Mo

976 Mediastinal paraganglioma: Utility of preoperative cardiac magnetic resonance imaging

Davinder S. Jassal, MD, FRCPC, Umaima Fatima, MD, Amar Thakrar, MD,

Tomas G. Neilan, MD, Norma Rodriguez, MD, Andrew Rosenberg, MD, and

Godtfred Holmvang, MD, Boston, Mass, Winnipeg, Manitoba, Canada, and Saskatoon,

Saskatchewan, Canada

978 Telescoping bronchial anastomosis for extended sleeve lobectomy Shinichiro Miyoshi, MD, PhD, Motohiko Tamura, MD, PhD, Osamu Araki, MD, Naoko Yoshii, MD, PhD, Yoko Karube, MD, PhD, Norio Seki, MD, Hideo Umezu, MD, Satoru Kobayashi, MD, PhD, Hiromi Ishihama, MD, Sensuke Nagai, MD, PhD, and Noriyoshi Sawabata, MD, PhD, Tochigi, Japan

980 Simultaneous heart valve replacement and reconstruction of the radiation-damaged chest wall with a delayed vertical rectus abdominis myocutaneous flap Thomas Strecker, MD, Richard Feyrer, MD, Raymund E. Horch, MD, Michael Weyand, MD, and Ulrich Kneser, MD, Erlangen, Germany

982 Combined bronchial sleeve resection and repair of partial anomalous pulmonary venous return

Robert L. Smith II, MD, George L. Zorn III, MD, Benjamin B. Peeler, MD, and

David R. Jones, MD, Charlottesville, Va

984 Primary pulmonary plasmacytoma with immunoglobulin G/ $\lambda$ light chain monoclonal gammopathy

Chin-Chih Chang, MD, Yih-Leong Chang, MD, Li-Na Lee, MD, PhD, and

Yung-Chie Lee, MD, PhD, Taipei, Taiwan 
986 Large chondrosarcoma of the rib invading the mediastinum and the spine Hideo Morioka, MD, PhD, Hiroo Yabe, MD, PhD, Shinjiro Kaneko, MD, PhD,

Hironari Takaishi, MD, PhD, Toshihiko Ueda, MD, PhD, Masazumi Watanabe, MD, PhD,

Koichi Kobayashi, MD, PhD, and Yoshiaki Toyama, MD, PhD, Tokyo and Utsunomiya, Japan

\section{Letters to the Editor}

988

Candidate gene association analysis of thoracic aortic aneurysm and dissection

Usman Ahmad, MBBS, Muhammad A. Javed, MD, and Saulat H. Fatimi, MD, FACS, Karach, Pakistan

988 Reply

Li Chen, PhD, Xing Li Wang, MD, PhD, Joseph S. Coselli, MD, and Scott A. LeMaire, MD,

Houston, Tex

989 Placement of the Impella Recover LD microaxial blood pump through a bioprosthesis is technically feasible

Andrea Garatti, MD, Tiziano Colombo, MD, and Ettore Vitali, MD, Milan, Italy

990 Off-pump pulmonary valve implantation

Christian Schreiber, MD, PhD, and Rüdiger Lange, MD, PhD, Munich, Germany

990 Reply

Pascal A. Berdat, MD, and Thierry P. Carrel, MD, Bern, Switzerland

991 Tracheal stents in patients with malignancy

Marco Anile, MD, Tiziano De Giacomo, MD, and Federico Venuta, MD, Rome, Italy

991 Reply

Jarmo Salo, MD, Prof, Thanos Sioris, MD, PhD, Jari Räsänen, MD, and

Eero Sihvo, MD, PhD, Helsinki, Finland

\section{Events of Interest}

\section{Announcements}

995

995

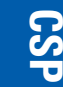

\section{Events}

\section{The American Association for Thoracic Surgery}

5 Announcement of 2007 Annual Meeting

996 Resident Traveling Fellowship, 2006-2007

996 Second Dwight Harken Research Scholarship, 2007-2009

997 The American Association for Thoracic Surgery Volunteer Leadership and Senior Staff Disclosure Statement

\section{The Western Thoracic Surgical Association}

998 Announcement of 2007 Annual Meeting 
998 Samson Resident Prize Essay

999 Application for Membership

The American Board of Thoracic Surgery

999 Notices

999 Requirements for Recertification/Maintenance of Certification

\section{Reader Services}

30A Information for Authors

35A Information for Readers

36A Copyright Transmittal Form

754 Change of address

795 Interactive eLearning Activities

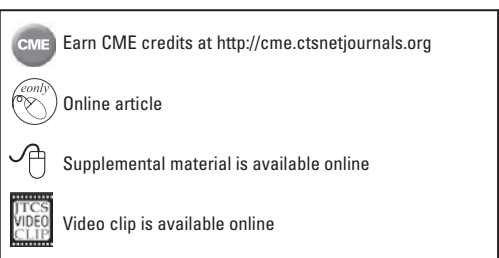

